\title{
Isolation and Characterization of a Protease-Producing Bacterium, Bacillus amyloliquefaciens P27 from Meju as a Probiotic Starter for Fermented Meat Products
}

\author{
Mi-Sun Lee, Na-Kyoung Lee, Kyung-Hoon Chang, Shin-Yang Choi ${ }^{1}$, \\ Chi-Kwang Song ${ }^{2}$, and Hyun-Dong Paik ${ }^{1, *}$ \\ Division of Animal Life Science and Bio/Molecular Informatics Center, Konkuk University, Seoul 143-701, Korea \\ ${ }^{1}$ Korea Food Research Institute, Seongnam 463-746, Korea \\ ${ }^{2}$ Food R\&D, CJ CheilJedang Corp., Seoul 152-050, Korea
}

\begin{abstract}
This study was performed to select protease-producing Bacillus sp. as a potential probiotic starter for fermented meat products. In order to isolate protease-producing bacterium from meju, measured the diameter of the clear zone on agar plate (TSA, $1 \%(\mathrm{w} / \mathrm{v})$ skim milk) and analyzed for intracellular protease activity, then 10 Bacillus-like strains were isolated. Three Bacillus-like strains (P19, P27, and P33) among 10 strains were able to tolerate in acidic condition (TSB, pH 2.5, 2 h incubation). These 3 strains were showed antimicrobial activity against food-borne pathogenic bacteria. These vegetative cells of 3 strains were showed a survival rate of $0.04 \%$ to $0.08 \%$ under the artificial gastric acidic condition (TSB, $\mathrm{pH} 2.5$ with $1 \%(\mathrm{w} / \mathrm{v})$ pepsin), but spore-forming cells were $56.29 \%$ to $84.77 \%$. Vegetative cells of 3 strains were the least bileresistant, while spore-forming cells of 3 strains showed higher survival rate more than $76 \%$ under artificial bile condition (TSB, $0.1 \%(w / v)$ oxgall bile). In these strains, P27 strain was finally selected as a good probiotic strain. P27 strain was tentatively identified as Bacillus amyloliquefaciens by API CHB kit and 16S rDNA sequence analysis. The results of this study suggest that B. amyloliquefaciens P27 can be used as a potential probiotic starter for fermented meat product.
\end{abstract}

Key words: Bacillus amyloliquefaciens, probiotic starter, protease-producing strain, meju, fermented meat product

\section{Introduction}

Recently, interest on the probiotics has been increasing and methods developed for human medicine and agriculture for which the mechanisms by which probiotics operate have been well defined. Probiotics are generally defined as live microbial feed supplements that can benefit the host by improving its intestinal balance (Chang and Liu, 2002; Fuller et al., 1989; Zhou et al., 2010). The presence of an adequate number of live probiotic cells in a food product at the time of consumption represents the first challenge for the development of a probiotic product, taking the recommended dose of at least $10^{8}$ cells/day into account (Hammes and Haller, 1998). Secondly, the probiotic cultures have ability to survive passage through the upper part of the gastrointestinal tract. High tolerance

\footnotetext{
*Corresponding author: Hyun-Dong Paik, Division of Animal Life Science and Bio/Molecular Informatics Center, Konkuk University, Seoul 143-701, Korea. Tel: 82-2-2049-6011, Fax: 82-2-455-1044, E-mail: hdpaik@konkuk.ac.kr
}

to low $\mathrm{pH}$ and bile salts corresponding to the conditions of the human gastrointestinal tract (GIT) has therefore been considered as important selection criteria (Tuomola et al., 2001).

Probiotic bacteria are mostly the lactic acid bacteria, such as the lactobacilli and bifidobacteria, partly sporeforming Bacillus species, or yeasts like Saccharomyces boulardii (Hoa et al., 2000). Many studies have demonstrated direct probiotics effects of Bacillus spores (Casula and Cutting, 2005; Sánchez et al., 2009). In addition, a large of Bacillus products are used as 'novel foods' or as dietary supplements with claim of 'enhancing' the wellbeing of the consumer (Hong et al., 2005).

Fermented foods are important part of traditional diets around the world especially, type of traditional fermented soybean food in Asian countries. Meju is a fermented rectangular block of crushed cooked soybeans and to make doenjang and kochujang, one of important traditional fermented foods in Korea. Healthful physiological effects of Korean fermented foods have received attention from public and industry (Kim et al., 2009b). Soybean and soy- 
containing foods are excellent and inexpensive suppliers of dietary proteins, carbohydrates, vitamins, and minerals (Anderson et al., 1995; Cho, 2008; Sung et al., 2004). One of Korean soybean fermented soybean foods, meju is major source of protein of Korean for thousands of years. Meju is necessary to produce all kind of bacteria for fermentation of doenjang and the majority of species is Bacillus sp. (B. subtilis, B. licheniformis, B. amyloliquefaciens, and B. pumilus). The producing-protease bacteria help digestion because their protease decomposes protein into amino acid.

Microbial proteases from bacteria, yeast and molds have also been developed for meat tenderization (Diaz et al., 1997; Kim et al., 2008). In particular, protease from Bacillus sp. have become the most important industrial enzymes based on the world-wide enzyme sales (Park et al., 2005). The crude protease(s) from B. polyfermenticus SCD treated jerky was good affected on quality than those of control (Kim et al., 2008). For B. subtilis, safety in humans is already supported by the fact that $B$. subtilis is a long history of beneficial properties assigned such as natto or as food supplements (as in Lactipan Plus in Italy) (Hong et al., 2008). Therefore, Bacillus sp. has probiotic properties could be used as starter culture for fermented meat products instead of lactic acid bacteria such as the traditional Japanese staple.

Through this study, protease-producing bacteria from meju was screened and characterized probiotic characteristics of selected Bacillus-like strains that including their resistances to artificial gastric juice and artificial bile acid, and antimicrobial activity. In next, B. amyloliquefacies $\mathrm{P} 27$ will be used as a probiotic and starter culture for fermented meat products.

\section{Materials and Methods}

\section{Preparation of meju and isolation of Bacillus-like strains}

Meju were obtained from local market and Bacilluslike strains were isolated from these products. Each sample $(10 \mathrm{~g})$ was dissolved in $90 \mathrm{~mL}$ of $0.85 \%$ (w/v) $\mathrm{NaCl}$. After dilution, $0.1 \mathrm{~mL}$ of the diluted suspension was spread on the plate count agar (PCA, Difco, Benton Dickinson, Sparks, MD, USA) plates followed by incubation at $37^{\circ} \mathrm{C}$ for $24 \mathrm{~h}$. Colonies showing Bacillus-like strains were selected as a pure isolate on each TSA plate. Each strain was stored at $-70^{\circ} \mathrm{C}$ as a stock solution in $30 \%(\mathrm{v} /$ v) glycerol during the experiments.

\section{Screening of protease-producing bacteria}

Selection of the strain with protease activity was performed by TSA with $1 \%(\mathrm{w} / \mathrm{v})$ skim milk. Each strain was spotted on TSA plates by the toothpick method (Yun et al., 2003). After incubation at $30^{\circ} \mathrm{C}$ for $16 \mathrm{~h}$, the diameter of the clear zone on agar plate was measured and isolated colonies that over $25 \mathrm{~mm}$ clear zone size were used for 2nd screening.

Each of the isolated colonies from 1st screening were inoculated in $7 \mathrm{~mL} \mathrm{TSB}$ at $30^{\circ} \mathrm{C}$ for $16 \mathrm{~h}$. Supernatant of TSB culture solution was obtained by centrifuging at $22,000 \mathrm{~g}$ for $20 \mathrm{~min}$ and $1 \mathrm{~mL}$ of the supernatant were used as enzyme solution to measure protease activity (Jung et al., 2008). This enzyme reaction was carried out by adding $0.5 \mathrm{~mL}$ of enzyme solution to $1.5 \mathrm{~mL}$ of $2 \%$ casein solution, $1 \mathrm{~mL}$ of Mcllavain buffer $(\mathrm{pH}$ 6.0) at $38^{\circ} \mathrm{C}$ for $1 \mathrm{~h}$. The reaction was stopped by adding $3 \mathrm{~mL}$ of $0.4 \mathrm{M}$ trichloroacetic acid (TCA), and the solution was allowed to stand at $38^{\circ} \mathrm{C}$ for $15 \mathrm{~min}$. After that, the mixture was centrifuged at 3,000 $\mathrm{g}$ for $20 \mathrm{~min}$, and $1.0 \mathrm{~mL}$ of the supernatant was used for next measurement. One $\mathrm{mL}$ of the supernatant was mixed with $5 \mathrm{~mL}$ of $0.4 \mathrm{M}$ $\mathrm{Na}_{2} \mathrm{CO}_{3}$ solution and $1 \mathrm{~mL}$ of $1 \mathrm{~N}$ Folin reagent, and the mixture was stood at $38^{\circ} \mathrm{C}$ for $30 \mathrm{~min}$. The absorbance of the above mixture was measured at $660 \mathrm{~nm}$ using a spectrophotometer (JASCO V-530, Tokyo, Japan), which was equivalent to the amount of converted tyrosine based on a standard curve. One unit of protease activity was defined as liberation of $1 \mu \mathrm{g}$ of tyrosine per minute.

\section{Tolerance to acidic condition on agar plate}

To determine the tolerance to acidic condition, the method of Hyronimus et al. (2000) was modified as follows. The isolated Bacillus strains were grown in TSB at $30^{\circ} \mathrm{C}$ for $16 \mathrm{~h}$, and diluted to $10^{6} \mathrm{CFU} / \mathrm{mL}$ in fresh TSB adjusted to different $\mathrm{pH}$ values $(2,3$, and 7 ) with $3 \mathrm{M}$ hydrochloric acid. After incubation at $37^{\circ} \mathrm{C}$ for $2 \mathrm{~h}$, each culture were streaked on the TSA plates $(\mathrm{pH} 7.0)$ and then incubated at $30^{\circ} \mathrm{C}$ for $16 \mathrm{~h}$.

\section{Antimicrobial activity of strains and supernatant concentrates}

Eighteen food-borne pathogenic bacteria were used as test organisms: Escherichia coli ATCC 9637, E. coli ATCC 10536, E. coli ATCC 25922, E. coli O157, Listeria monocytogenes ATCC 15313, Salmonella Enteritidis KCCM 12021, Salmonella Typhimurium P99, S. Typhimurium ATCC 14028, Staphylococcus aureus ATCC 14458, S. aureus ATCC 25923, S. aureus KCCM 32395, 
S. aureus KCCM 40510, Staphylococcus epidermidis ATCC 12228, Streptococcus agalactiae ATCC 13813, S. agalactiae ATCC 14364, Pseudomonas aeruginosa ATCC 15522, Bacillus cereus ATCC 9634, B. cereus ATCC 11778. These test organisms were grown on the TSA plates at $37^{\circ} \mathrm{C}$ for $24 \mathrm{~h}$.

The isolated Bacillus strains were cultured in $100 \mathrm{~mL}$ $\mathrm{TSB}$ at $30^{\circ} \mathrm{C}$ for $12 \mathrm{~h}$ in shaking incubator $150 \mathrm{rpm}$. Antimicrobial activity was measured as two methods. The first one was flip method. The isolated Bacillus strain streaked on TSA plates after that incubated at $30^{\circ} \mathrm{C}$ for $16 \mathrm{~h}$. Then agars which grown the Bacillus strain flipped to top of plates and overlaid $5 \mathrm{~mL}$ of each soft agar (TSA, $0.8 \%(\mathrm{w} / \mathrm{v})$ agar) inoculated $100 \mu \mathrm{L}$ of indicator strains. After incubation at $37^{\circ} \mathrm{C}$ for $24 \mathrm{~h}$, the antimicrobial activity was measured the clear zone around the isolated Bacillus strains. The second one was paper disc method. That is, the Bacillus cultured cells were removed from the medium by centrifugation at $22,000 \mathrm{~g}$ for $20 \mathrm{~min}$, and the supernatant filtered through a $0.45 \mu \mathrm{m}$ syringe filter (Toyo Roshi Kaisha, Tokyo, Japan). After filtration, $20 \mathrm{~mL}$ of the supernatant was lyophilized for concentration. The TSA plates were prepared for antimicrobial activity which was spread with a test organism, and put on 8-mm paper disc. For preparing 10 times concentrates, lyophilized supernatant was dissolved in $2 \mathrm{~mL}$ sterile phosphate buffered saline (PBS, pH 7.0) before using. Fifty microliter of 10 times concentrates was applied on to the $8-\mathrm{mm}$ paper disc. After incubation at $37^{\circ} \mathrm{C}$ for $24 \mathrm{~h}$, the antimicrobial activity was measured as the diameter $(\mathrm{mm})$ of the clear zone.

\section{Tolerance to artificial gastric juice and artificial bile acid}

The artificial gastric juice and artificial bile acid tolerance of Bacillus sp. were studied on 2 types of vegetative cells and spore-forming cells. Spores were formed by heating at 80 for $30 \mathrm{~min}$ after incubation at $30^{\circ} \mathrm{C}$ for $48 \mathrm{~h}$.

To investigate survival of Bacillus sp. cultures under artificial gastric juice condition, strain culture inoculated (1\%) into TS broth that had been acidified to $\mathrm{pH} 2.5$ (using $\mathrm{HCl}$ ) containing $1 \%$ of pepsin and incubated at $37^{\circ} \mathrm{C}$ for $2 \mathrm{~h}$. After that to estimate bile tolerance of Bacillus sp. cultures, each strain cultures inoculated (1\%) into TS broth containing $0.1 \%$ oxgall bile and incubated at $37^{\circ} \mathrm{C}$ for $24 \mathrm{~h}$. Then, the number of viable Bacillus sp. cells was determined by serial dilution with $0.85 \% \mathrm{NaCl}$ and spread on TSA plates. Plates were incubated at $30^{\circ} \mathrm{C}$ for $12 \mathrm{~h}$, and the survival rate was calculated as the per- centage of Bacillus sp. grown on the TSA plates.

\section{Microbial identification of probiotic strains}

Cell morphology, gram staining, carbohydrate usability, and 16 rDNA sequencing were analyzed for the tentative microbial identification of probiotic strains. Test culture was grown on TSA plates at $30^{\circ} \mathrm{C}$ for $16 \mathrm{~h}$, and then inoculated onto test media for biochemical tests with commercial API 50 CHB kit (ATB System, bioMerieux, Marcy l'Etoile, France). The colonies were suspended in API $50 \mathrm{CHB}$ medium and the strips were inoculated then, incubated at $37^{\circ} \mathrm{C}$ and observed at 24 and $48 \mathrm{~h}$. Among these strains, P27 strain was additionally identified by using the $16 \mathrm{rDNA}$ sequence performed by Macrogen (Seoul, Korea), the sequence was determined by BLAST program of GENEBANK data library.

\section{Results and Discussion}

\section{Screening of protease-producing bacteria from теји}

Thirteen kinds of Korean traditional meju were collected from local market and 471 Bacillus-like strains were isolated from these products. The presence of various Bacillus sp. in meju and other soy fermented foods (doenjang and kochujang) was reported (Cho, 2008; Jung et al., 2008; Mo et al., 2010; Yun et al., 2003). Sixty-nine Bacillus-like strains with protease activity were isolated using TSA plate with $1 \%(\mathrm{w} / \mathrm{v})$ skim milk using the toothpick method. A clear zone around strains suggested production of the protease by the Bacillus-like strains.

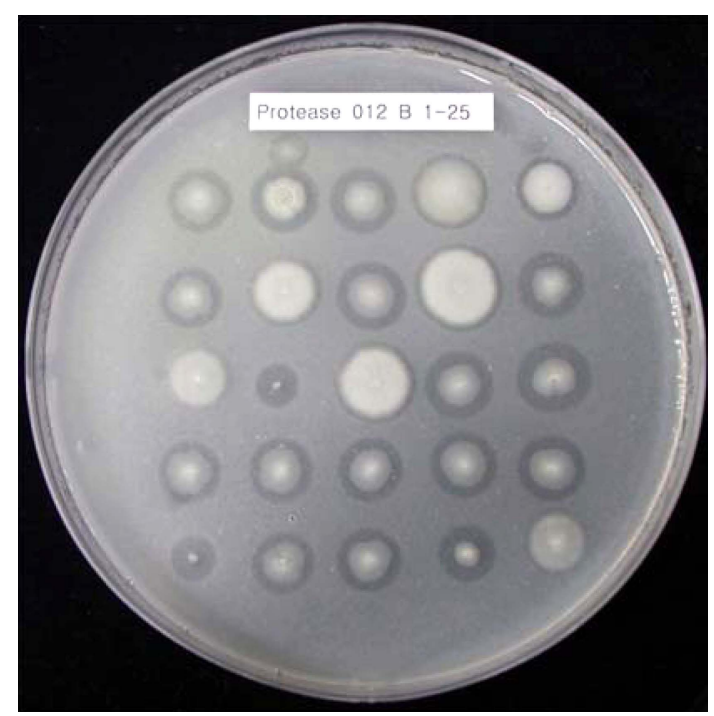

Fig. 1. Example of isolation of protease-producing Bacilluslike strains. 
These 69 isolated strains which exhibited higher protease activities with over $25 \mathrm{~mm}$ a clear zone (Fig. 1), then strains were analyzed for intracellular protease activity.

For intracellular protease activities of the 69 isolated strains, the strain was cultivated in TSB medium at $30^{\circ} \mathrm{C}$ for $16 \mathrm{~h}$. After determination of protease activity, 10 strains showing high protease activities were selected for determining their acidic tolerance. The protease activity of P19, P27, and P33 strains was 0.98 $\pm 0.20,1.42 \pm 0.15$, and $0.84 \pm 0.03 \mathrm{U} / \mathrm{mL}$, respectively.

\section{Tolerance to acidic condition on agar plate}

Ten selected strains were using to confirm their tolerance to acidic condition. Seven strains inoculated TS broth at pH 2 and 3 showed lower growth on TSA plate than the other 3 strains. Three strains of P19, P27, and P33 showed growth on TSA plates as control. Therefore, three strains were selected for further study.

Table 1. Antimicrobial activities of protease-producing strains isolated from mејu against food-borne pathogenic bacteria

\begin{tabular}{|c|c|c|c|c|c|c|}
\hline \multirow[t]{2}{*}{ Indicator Strains } & \multicolumn{3}{|c|}{$\begin{array}{l}\text { Size of inhibi- } \\
\text { tory clear zone } \\
\text { by flip method }\end{array}$} & \multicolumn{3}{|c|}{$\begin{array}{c}\text { Diameter }(\mathrm{mm}) \text { of } \\
\text { inhibitory clear } \\
\text { zone by disc } \\
\text { method }\end{array}$} \\
\hline & P19 & P27 & P33 & P19 & $\mathrm{P} 27$ & P33 \\
\hline E. coli ATCC 9637 & - & - & - & - & - & - \\
\hline E. coli ATCC 10536 & $-1)$ & - & - & - & - & - \\
\hline E. coli ATCC 25922 & - & - & - & - & - & - \\
\hline E. coli $\mathrm{O} 157$ & - & - & - & - & - & - \\
\hline L. monocytogenes ATCC 15313 & ++ & ++ & ++ & $12.5^{5)}$ & 15.0 & - \\
\hline S. Enteritidis KCCM 12021 & - & - & - & - & - & - \\
\hline S. Typhimurium P99 & - & - & - & - & - & - \\
\hline S. Typhimurium ATCC 14028 & - & - & - & - & - & - \\
\hline S. aureus ATCC 14458 & ++ & ++ & ++ & - & - & - \\
\hline S. aureus ATCC 25923 & $+^{2)}$ & + & + & - & - & - \\
\hline S. aureus KCCM 32395 & ++ & ++ & ++ & 11.0 & 10.5 & - \\
\hline S. aureus KCCM 40510 & $+^{3)}$ & + & + & - & - & - \\
\hline S. epidermidis ATCC 12228 & $++^{4)}$ & ++ & ++ & 14.5 & 15.0 & - \\
\hline S. agalactiae ATCC 13813 & ++ & ++ & ++ & - & 12.0 & - \\
\hline S. agalactiae ATCC 14364 & + & + & + & - & 11.0 & - \\
\hline P. aeruginosa ATCC 15522 & - & - & - & - & - & - \\
\hline B. cereus ATCC 9634 & + & ++ & ++ & 11.5 & 11.5 & 10.5 \\
\hline B. cereus ATCC 11778 & + & + & + & 11.0 & 11.5 & 10.5 \\
\hline
\end{tabular}

\section{Antimicrobial activity of strains and supernatant concentrations}

Antimicrobial activities of the selected 3 strains were tested against 18 food-borne pathogenic bacteria in this study. Flip method showed a broad range of antimicrobial activities against food-borne pathogenic bacteria than paper disc method (Table 1).

Using Flip method, isolated 3 strains showed antimicrobial activity against food-borne pathogenic bacteria including L. monocytogenes ATCC 15313, S. aureus ATCC 14458, $S$. aureus ATCC 25923, S. aureus KCCM 32395, S. epidermidis ATCC 12228, S. agalactiae ATCC 13813, S. agalactiae ATCC 14364, B. cereus ATCC 9634, and B. cereus ATCC 11778.
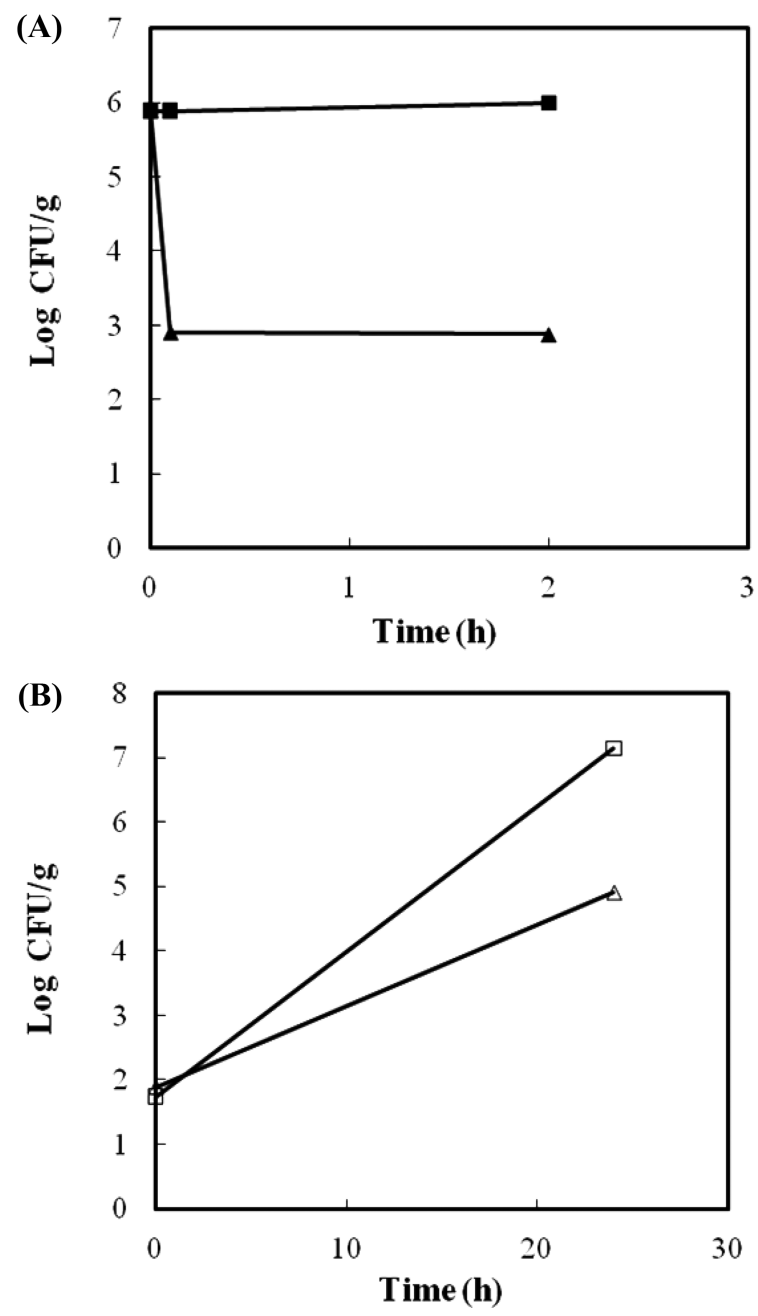

Fig. 2. Survival of vegetative cells of strain P27 in (a) artificial gastric juice, (b) treated with artificial bile acid after artificial gastric juice treatment $\left(\mathrm{pH} \mathrm{2.5)}\right.$ at $37^{\circ} \mathrm{C}$ for $\mathbf{2} \mathbf{h}$. $\mathbf{q}$, no artificial gastric juice treatment (control); $\Delta$, treated with artificial gastric juice ( $\mathrm{pH} \mathrm{2.5);} \square$, no bile acid added after treatment with artificial gastric juice (control); $\triangle$, treated with artificial gastric juice ( $\mathrm{pH} 2.5$ ) and bile acid. 

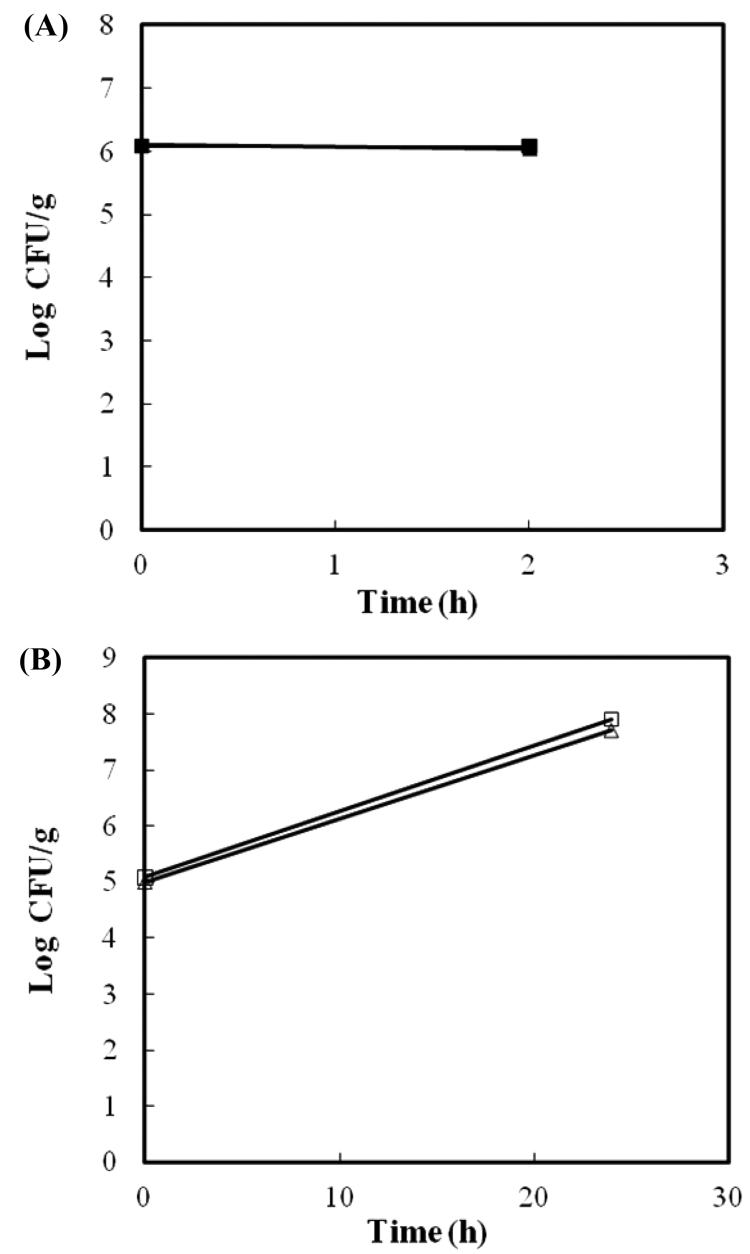

Fig. 3. Survival of spore-forming cells of strain P27 in (a) artificial gastric juice, (b) treated with artificial bile acid after artificial gastric juice treatment $\left(\mathrm{pH} \mathrm{2.5)}\right.$ at $37^{\circ} \mathrm{C}$ for $\mathbf{2} \mathbf{h}$. $\boldsymbol{\square}$, no artificial gastric juice treatment (control); $\boldsymbol{\Delta}$, treated with artificial gastric juice ( $\mathrm{pH} 2.5$ ); $\square$, no bile acid added after treatment with artificial gastric juice (control); $\triangle$, treated with artificial gastric juice $(\mathrm{pH} 2.5)$ and bile acid.
However, using paper disc method, inoculated 10 times concentrates showed different results between each strain. P27 strain showed relatively wide antimicrobial spectrum against L. monocytogenes ATCC 15313, S. aureus KCCM 32395, S. epidermidis ATCC 12228, S. agalactiae ATCC 13813, S. agalactiae ATCC 14364, B. cereus ATCC 9634, and B. cereus ATCC 11778.

Several Bacillus sp. is reported as the production of antimcirobial substances including organic acid, hydrogen peroxide, ethanol, and bacteriocin against food-borne pathogens (Cho, 2008; Kim et al., 2009a; Wilson et al., 2005). In this study, the concentrates of P27 strain has antimicrobial effect against several food-borne pathogens, this result represents the possibility of usable biocontrol substances.

\section{Tolerance to artificial gastric juice and artificial bile acid}

The important characteristics of probiotics is resistant to gastric and bile acids, as they pass through the duodenum in order to reach the small intestinal tract (Mainville et al., 2005). Our study was investigated as 2 types of vegetative cells and spore-forming cells for the tolerance to artificial gastric juice and artificial bile acid. Survivals in artificial gastric juice are shown in Table 2 and survivals in artificial bile acid are shown in Table 3. Vegetative cells of 3 strains were showed a low survival rate of 0.04 to $0.08 \%$, whereas spore-forming cells were showed a high survival rate of 56.29 to $84.77 \%$ under the artificial gastric acidic condition. The vegetative cells of 3 strains were the least bile-resistant (Table 2). However, sporeforming cells of 3 strains showed higher survival rate more than $76 \%$ in artificial bile acid shown as Table 3 . In

Table 2. Viability of vegetative cells and spore-forming cells of protease-producing strains isolated from meju in artificial gastric juice

\begin{tabular}{|c|c|c|c|c|c|c|}
\hline \multirow{2}{*}{ Strain } & \multicolumn{3}{|c|}{ Vegetative cell (CFU/mL) } & \multicolumn{3}{|c|}{ Spore forming cell (CFU/mL) } \\
\hline & Control & $1 \%$ Pepsin (pH 2.5) & Viability (\%) & Control & $1 \%$ Pepsin (pH 2.5) & Viability (\%) \\
\hline P19 & $2.1 \times 10^{6}$ & $8.0 \times 10^{2}$ & 0.04 & $4.1 \times 10^{5}$ & $3.5 \times 10^{5}$ & 84.77 \\
\hline P27 & $9.9 \times 10^{5}$ & $7.5 \times 10^{2}$ & 0.08 & $1.2 \times 10^{6}$ & $1.1 \times 10^{6}$ & 84.62 \\
\hline P33 & $6.3 \times 10^{5}$ & $4.5 \times 10^{2}$ & 0.07 & $5.4 \times 10^{5}$ & $3.0 \times 10^{5}$ & 56.29 \\
\hline
\end{tabular}

Table 3. Viability of vegetative cells and spore-forming cells of protease-producing strains isolated from meju in artificial bile acid after artificial gastric juice treatment

\begin{tabular}{ccccccccc}
\hline \hline \multirow{2}{*}{ Strain } & \multicolumn{3}{c}{ Vegetative cell $(\mathrm{CFU} / \mathrm{mL})$} & & \multicolumn{3}{c}{ Spore forming cell $(\mathrm{CFU} / \mathrm{mL})$} \\
\cline { 2 - 4 } & Control & $0.1 \%$ Oxgall & Viability $(\%)$ & & Control & & $0.1 \%$ Oxgall & Viability (\%) \\
\hline P19 & $5.4 \times 10^{6}$ & $5.0 \times 10^{0}$ & 0.00 & & $4.9 \times 10^{7}$ & $5.2 \times 10^{7}$ & 106.46 \\
P27 & $1.4 \times 10^{7}$ & $5.9 \times 10^{4}$ & 0.42 & & $6.7 \times 10^{7}$ & $5.1 \times 10^{7}$ & 76.50 \\
P33 & $1.1 \times 10^{8}$ & $4.9 \times 10^{4}$ & 0.04 & & $1.6 \times 10^{7}$ & $1.3 \times 10^{7}$ & 83.46 \\
\hline
\end{tabular}




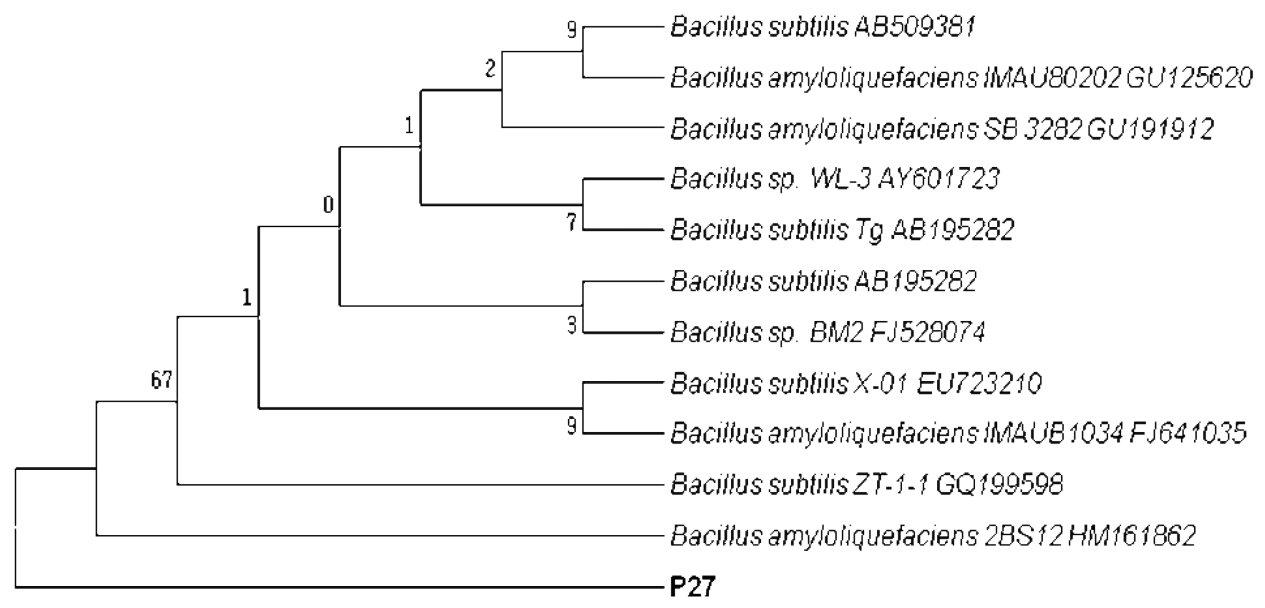

Fig. 4. Phylogenetic tree based on 16S rDNA sequences showing the position of strain P27 and representatives of some related taxa.

most study using spore-forming cells of Bacillus, their data showed high survival in artificial gastric juice and artificial bile acid (Cho, 2008; Patel et al., 2009).

\section{Microbial identification of probiotic strains}

Identification using API 50 CHB kit showed strain P19 to have $77.1 \%$ similarity to Bacillus subtilis/Bacillus amyloliquefaciens, strain P27 to have 98.5\% similarity to Bacillus subtilis/Bacillus amyloliquefaciens, and strain P33 to have $97.5 \%$ similarity to Bacillus subtilis/Bacillus amyloliquefaciens.

P27 strain showed the best probiotic characteristics among 3 strains studied. Therefore, for the specific identification, P27 strain was identified through the 16S rDNA sequence analysis. The result of $16 \mathrm{~S}$ rDNA sequence showed 97\% identities with Bacillus amyloliquefaciens 16s rDNA sequence of GENBANK (Fig. 4).

In conclusion, this study showed that protease-producing bacterium was screened from meju and investigated probiotic characteristics. Among these isolates, B. amyloliquefaciens P27 has a highest protease, high survival in artificial gastric juice and artificial bile acid, and wide range of antimicrobial activity. On the basis of these results, B. amyloliquefaciens P27 could be a good possible probiotics and a fermentation starter for fermented meat product in next study.

\section{Acknowledgment}

This work was supported by Priority Research Centers Program through the National Research Foundation of Korea (NRF) funded by the Ministry of Education, Science and Technology (2009-0093824).

\section{References}

1. Anderson, R. L. and Wolf, W. J. (1995) Compositional changes in trypsin inhibitors, phytic acid, saponins and isoflavones related to soybean processing. J. Nutr. 125, $581 \mathrm{~S}-588 \mathrm{~S}$.

2. Casula, G. and Cutting, S. M. (2002) Bacillus probiotics: Spore germination in the gastrointestinal tract. Appl. Environ. Microbiol. 68, 2344-2352.

3. Chang, C. I. and Liu, W. Y. (2002) An evaluation of two probiotic bacterial strains, Enterococcus faecium SF 68 and Bacillus toyoi, for reducing edwardsiellosis in cultured European eel, Anguilla anguilla L. J. Fish Dis. 25, 311-315.

4. Cho, K. M. (2008) Characterization of potential probiotics Bacillus subtilis CS90 from soybean paste (Doenjang) and its antimicrobial activity against food-borne pathogens. $J$. Appl. Biol. Chem. 51, 285-291.

5. Diaz, O., Fernandez, M., Fernando, G. D. G., Hoz, L., and Ordones, J. A. (1997) Proteolysis in dry fermented sausage: The effect of selected exogenous protease. Meat Sci. 46, 115128.

6. Fuller, R. (1989) Probiotics in man and animals. J. Appl. Bacteriol. 66, 365-378.

7. Hammers, W. P. and Haller, D. (1998) What is known about the effect of probiotics in meat product? Fleischwirtschaft 78, 301-306.

8. Hoa, N. T., Baccigalupi, L., Huxham, A., Smertenko, A., Van, P. H., Ammendola, S., Ricca, E., and Cutting, A. S. (2000) Characterization of Bacillus species used for oral bacteriotherapy and bacterioprophylaxis of gastrointestinal disorders. Appl. Environ. Microbiol. 66, 5241-5247.

9. Hong, H. A., Due Ie, H., and Cutting, S. M. (2005) The use of bacterial spore formers as probiotics. FEMS Microbiol. Rev. 29, 813-835.

10. Hong, H. A., Huang, J. M., Khaneja, R., Hiep, L. V., Urdaco, M. C., and Cutting, S. M. (2008) The safety of Bacillus subtilis and Bacillus indicus as food probiotics. J. Appl. Microbiol. 105, 510-520. 
11. Hyronimus, B., Le Marrec, C., Hadj Sassi, A., and Deshamps, A. (2000) Acid and bile tolerance or spore-forming lactic acid bacteria. Int. J. Food Microbiol. 61, 193-197.

12. Jung, S. T., Kim, M. H., Shin, D. H., and Kim, Y. S. (2008) Isolation and identification of Bacillus sp. with high protease and amylase activity from Sunchang traditional kochujang. Food Sci. Biotechnol. 17, 519-526.

13. Kim, J. M., Choi, J. H., Han, D. J., Choi, Y. S., Jeong, J. Y., Choi, G. H., Paik, H. D., and Kim, C. J. (2008) Effect of protease produced from Bacillus polyfermenticus SCD on Quality of jerky. Food Sci. Biotechnol. 17. 389-395.

14.Kim, K. M., Lee, J. Y., Kim, C. K., and Kang, J. S. (2009a) Isolation and characterization of surfactin produced by Bacillus polyfermenticus KJS-2. Arch. Pharm. Res. 32, 711715.

15. Kim, S. Y., Son, H. S., and Oh, S. H. (2009b) Characteristics of Korean soybean paste (Doenjang) prepared by the fermentation of black soybeans. J. Food. Sci. Nutr. 14, 134-141.

16. Mainville, I., Arcand, Y., and Farnworth, E. R. (2005) A dynamic model that simulates the human upper gastrointestinal tract for the study of probiotics. Int. J. Food Microbiol. 99, 287-296.

17. Mo, A. Y., Kwon, B., Kamala-Kannan, S., Lee, K. J., Oh, B. T., Kim, D. H., Yang, M. S., Kim, J. H., and Park, S. M. (2010) Isolation and characterization of Bacillus polyfermenticus isolated from Meju, Korean soybean fermentation starter. World J. Microbiol. Biotechnol. 26, 1099-1105.

18. Park, E., Park, J. S., Choi, S. Y., Kim, K. T., and Paik, H.-D. (2005) Influence of functional food containing Bacillus polyfermenticus SCD on lipid and antioxidant metabolisms in rats fed a high-fat and high-cholesterol diet. Food Sci. Bio- technol. 14, 766-771.

19. Patel, A. K., Ahire, J. J., Pawar, S. P., Chaudhari, B. L., and Cincholkar, S. B. (2009) Comparative accounts of probiotic characteristic of Bacillus spp. isolated from food wastes. Food Res. Int. 42, 505-510.

20. Sánchez, B., Arias, S., Chaignepain, S., Denayrolles, M., Schmitter, J. M., Bressollier, P., and Urdaci, M. C. (2009) Identification of surface proteins involved in the adhesion of a probiotic Bacillus cereus strain to mucin and fibronectin. Microbiology 155, 1708-1716.

21. Sung, J. H., Choi, S. J., Lee, S. W., Park, K. H., and Moon, T. W. (2004) Isoflavones found in Korean soybean paste as 3hydroxy-3-methylglutaryl coenzyme a reductase inhibitors. Biosci. Biotechnol. Biochem. 68, 1051-1058.

22. Tuomola, E., Crittenden, R., Playne, M., Isolauri, E., and Salminen, S. (2001) Quality assurance criteria for probiotic bacteria. Am. J. Clin. Nutr. 73. 793S-398S.

23. Wilson, A. R., Sigree, D., and Epton, H. A. S. (2005) Antibacterial activity of Lactobacillus plantarum strain SK1 against Listeria monocytogenes is due to lactic acid production. J. Appl. Microbiol. 99, 1516-1522.

24. Yun, G. H., Lee, E. T., and Kim, S. D. (2003) Purification and characterization of a fibrinolytic enzyme produced from Bacillus amyloliquefaciens K42 isolated from Korean soy sauce. Korean J. Microbiol. Biotechnol. 31, 284-291.

25. Zhou, X., Wang, Y., Gu, Q., and Li, W. (2010) Effect of dietary probiotic, Bacillus coagulans, on growth performance, chemical composition, and meat quality of Guangxi Yellow chicken. Poultry Sci. 89, 588-593.

(Received 2010.9.15/Accepted 2010.10.19) 